Gatot DHW. Aspek Hukum dan...

\title{
Aspek Hukum Dan Kelembagaan Dalam Peningkatan Efisiensi Dan Efektivitas Pengelolaan Wilayah Pesisir ${ }^{1}$
}

\author{
Gatot Dwi Hendro Wibowo \\ Fakultas Hukum Universitas Mataram \\ Jl. Majapahit No. 62 Telp. (0370) 633035, Fax (0370) 640189 \\ epwnusra@yahoo.com
}

\begin{abstract}
This research is intended to identify about the regulation and institution related to management of coastal area. Regarding the subject matter of this study, this research is a normative legal research. It employed several approach, i.e. conceptual approach and statutory approach.

From this research, find out that (1) the authority of coastal area management can be find in sectoral regulation as such as tourism, environmental, land, mining, forestry regulation, etc. It consequence that many institution will be take about the coastal authority, (2) From the Institutional of view, the activities of cross sectoral, overlapping and potentialy conflict of authority, all of this, need the instotutional system with integration and coordination priority (3) The institutional approach by clear authority, strong institution and good procedure, can be increase efectively management of sustainable coastal area.
\end{abstract}

Keywords: Institutional Approach ; Efectively Management of Coastal Area

\section{Pendahuluan \\ Pembahasan terhadap tema di atas, sekurang-kurangnya mengandung 3 variabel, yaitu : aspek hukumnya sendiri, aspek kelembagaan dan aspek efisiensi dan efektivitas dalam pengelolaan wilayah pesisir. Aspek hukum memiliki spektrum yang sangat luas serta}

\footnotetext{
${ }^{1}$ Sebagian materi tulisan ini pernah disampaikan pada Pelatihan Training of Trainers Perencanaan Pengelolaan Pesisir Secara Terpadu (Integrated Coastal Zone Planning Management (ICZPM) tanggal 6 - 18 Nopember 2006 di Hotel Bintang Senggigi, Mataram - Nusa Tenggara Barat
} 
bisa didefinisikan dari berbagai sudut pandang atau perspektif. Untuk kebutuhan penelaahan makalah ini, penulis merujuk kepada pendapat Mochtar Kusumaatmadja, bahwa hukum pada dasarnya bukan hanya sekedar asas dan kaidah (norma), melainkan juga lembaga (institution) serta proses (process) dan prosedur yang mewujudkan hukum dalam kenyataan. Untuk melihat keterhubungan antara hukum dan kelembagaan maka hukum haruslah dimaknai sebagai wewenang (authority) yang perumusannya dijumpai dalam berbagai peraturan perundangundangan, adapun lembaga (institusi), dalam hal ini berfungsi untuk mewujudkan apa yang telah menjadi isi wewenang tersebut. Tegasnya, lembaga atau institusi memerlukan legitimasi wewenang, tanpa wewenang lembaga atau institusi tidak memiliki arti apa-apa. Sedangkan aspek efisiensi dan efektivitas, pada dasarnya merupakan aspek ekonomis yang diharapkan menjadi hasil dari sebuah proses pendekatan kelembagaan (Institutional Based Management) yang mengandalkan keterpaduan baik lembaga Pemerintah yang menangani pengelolaan sumber daya pesisir, maupun lembaga swasta serta lembaga masyarakat.

Berdasarkan logika berpikir di atas, maka pembahasan makalah ini akan diawali dengan pembahasan tentang wewenang dalam perspektif teoritik, dilanjutkan dengan wewenang pengelolaan sumberdaya pesisir, kemudian kajian kelembagaan, serta keterpaduan sebagai salah satu solusi kelembagaan dalam peningkatan efisiensi dan efektivitas dalam pengelolaan wilayah pesisir, selanjutnya diakhiri dengan beberapa simpulan.

\section{Konseptualisasi Wewenang}

Sebagai suatu konsep hukum publik, wewenang terdiri atas sekurangkurangnya tiga komponen, yaitu pengaruh, dasar hukum dan konformitas hukum. Komponen pengaruh ialah bahwa penggunaan wewenang dimaksudkan untuk mengendalikan perilaku subyek hukum. Komponen dasar hukum, bahwa wewenang itu selalu harus dapat ditunjuk dasar hukumnya dan komponen konformitas hukum, mengandung makna adanya standard wewenang, yaitu standard hukum (semua jenis wewenang) dan standard khusus (untuk jenis wewenang tertentu). ${ }^{2}$

${ }^{2}$ Philipus M. Hadjon, Tentang Wewenang, Yuridika, nomor 5 \& 6 XII SeptemberDesember, 1999, hlm. 2 
Dalam kepustakaan hukum administrasi terdapat dua cara utama untuk memperoleh wewenang pemerintahan, yaitu atribusi dan delegasi. Kadang-kadang mandat juga ditempatkan sebagai cara tersendiri untuk memperoleh wewenang.

Atribusi, merupakan wewenang untuk membuat keputusan (besluit) yang langsung bersumber kepada undang-undang dalam arti materiel. Rumusan lain mengatakan bahwa atribusi merupakan pembentukan wewenang tertentu dan pemberiannya kepada organ tertentu. Adapun yang dapat membentuk wewenang adalah organ yang berwenang berdasarkan peraturan perundang-undangan. Pembentukan wewenang dan distribusi wewenang utamanya ditetapkan dalam Undang Undang Dasar. Pembentukan wewenang pemerintahan didasarkan pada wewenang yang ditetapkan oleh peraturan perundang-undangan.

Delegasi, diartikan sebagai penyerahan wewenang (untuk membuat "besluit") oleh pejabat pemerintah kepada pihak lain dan wewenang tersebut menjadi tanggung jawab pihak lain tersebut. Yang memberi atau melimpahkan wewenang disebut delegans sedangkan yang menerima disebut delegataris. Pelimpahan wewenang dalam bentuk delegasi harus memenuhi syarat-syarat sebagai berikut :

a. Delegasi harus definitif, artinya delegans tidak dapat lagi menggunakan sendiri wewenang yang telah dilimpahkan itu.

b. Delegasi harus berdasarkan ketentuan peraturan perundangundangan, artinya delegasi hanya dimungkinkan kalau ada ketentuan untuk itu dalam peraturan perundang-undangan.

c. Delegasi tidak kepada bawahan, artinya dalam hubungan hirarki kepegawaian tidak diperkenankan adanya delegasi.

d. Kewajiban memberi keterangan (penjelasan), artinya delegans berwenang untuk meminta penjelasan tentang pelaksanaan wewenang tersebut.

e. Peraturan kebijakan (beleids-regel), artinya delegans memberikan instruksi (petunjuk) tentang penggunaan wewenang tersebut.

Berdasarkan persyaratan tersebut, maka Soewoto memberikan ciriciri pelimpahan wewenang atau delegasi sebagai berikut ${ }^{3}$

a. Pendelegasian harus dilakukan oleh badan yang berwenang;

b. Pendelegasian menyebabkan hilangnya wewenang bagi "delegans" dalam jangka waktu yang telah ditentukan ;

${ }^{3}$ Soewoto, Kekuasaan dan tanggung Jawab Presiden Republik Indonesia (disertasi), Fakultas Pasca Sarjana Universitas Airlangga, Surabaya, 1990, hlm. 75. 
c. Delegataris harus bertindak atas nama sendiri dan oleh karena itu seorang delegataris bertanggungjawab terhadap segala pelaksanaan kekuasaan yang timbul dari pendelegasian kekuasaan itu ;

d. "Sub-delegatie" baru dapat dilakukan walaupun tidak diatur dalam peraturan hukum

Mandat, merupakan suatu pelimpahan wewenang atau kekuasaan kepada bawahan. Mandataris atau siapa yang diberi mandat, melaksanakan wewenang tidak bertindak atas nama sendiri melainkan bertindak atas nama pemberi kuasa ("mandant"), oleh karena itu penerima mandat tidak memiliki tanggungjawab sendiri. Tanggungjawab dan tanggung gugat tetap berada pada pemberi mandat.

\section{Wewenang dalam Pengelolaan Sumber daya Pesisir}

Sebagaimana telah diutarakan di atas, bahwa dalam konsep wewenang selalu harus dapat ditunjuk dasar hukumnya, oleh karena itu untuk mengetahui lebih jauh mengenai wewenang pengelolaan sumberdaya pesisir dan lautan, perlu ditelusuri dasar hukumnya khususnya yang terdapat dalam peraturan perundang-undangan nasional.

Pasal 33 Undang-Undang Dasar 1945 ayat (3) menyebutkan :" bumi, air dan kekayaan alam yang terkandung di dalamnya adalah karunia Tuhan Yang Maha Esa dan dikuasai oleh Negara untuk sebesar-besar kemakmuran rakyat".

Undang-Undang Dasar 1945 menggunakan kata "dikuasai" sebagai legitimasi kewenangan negara atas sumberdaya alam dan lingkungan. Kendatipun banyak menuai protes dari berbagai elemen masyarakat khususnya dari kalangan NGO mengenai terminologi "dikuasai" tersebut, namun wakil rakyat di DPR/MPR tetap mempertahankan istilah "dikuasai" pada Undang-Undang Dasar 1945 hasil amandemen, sehingga secara legalistik-formal, istilah "dikuasai oleh negara" mengandung arti bahwa negara memiliki kewenangan secara atributif dalam pengelolaan bumi, air dan kekayaan alam yang terkandung di dalamnya. Bagir Manan, merumuskan cakupan pengertian "dikuasai negara" antara lain penguasaan semacam pemilikan oleh negara, artinya negara melalui pemerintah (pusat) satu-satunya pemegang wewenang untuk menentukan hak wewenang atasnya termasuk bumi, air dan kekayaan alam yang terkandung di dalamnya. Dalam pengertian Pasal 33 UUD 1945, yang dimaksudkan dengan air, di samping air yang berada di daratan terlebih- 
lebih lagi yang berada di pesisir dan lautan. ${ }^{4}$

Undang-Undang Nomor 25 Tahun 2000 tentang Program Pembangunan Nasional (Propenas) Tahun 2000 - 2004) pada Bab X Pembangunan Sumberdaya alam dan Pelestarian fungsi Lingkungan Hidup, antara lain menyatakan :"Kegiatan pokok yang dilakukan adalah (1) Penyusunan Undang-undang Pengelolaan Sumber daya Alam berikut perangkat peraturannya...". Kendatipun sudah ada mandat untuk melakukan penyusunan undang-undang Sumber daya Alam, bahkan telah berulangkali dilakukan ekspose gagasan di beberapa daerah mengenai urgensinya undang-undang tersebut, namun sampai saat ini undang-undang tersebut belum diundangkan.

Undang-Undang Nomor 17 Tahun 1985, mengatur tentang Pengesahan United Nations Convention on the Law of the Sea (Konvensi Perserikatan Bangsa-Bangsa tentang Hukum Laut). Dalam undangundang ini, ditegaskan bahwa negara mempunyai kewajiban untuk melindungi dan melestarikan lingkungan laut, Article 192 menyebutkan, :"state have the obligation to protect and preserve the marine environment". Di samping itu, negara juga mempunyai hak berdaulat untuk mengeksploitasi kekayaan alam mereka serasi dengan kebijaksanaan lingkungan mereka serta sesuai pula dengan kewajiban mereka untuk melindungi dan melestarikan lingkungan laut. Article 193, menyebutkan, :"States have the sovereign right to exploit teir natural pursuant to their environmental policies and in accordance with their duty to protect and preserve the marine environment".

Dalam undang-undang nomor 17 Tahun 1985 tentang Pengesahan UNCLOS maupun Undang-Undang 5 tahun 1983 tentang Zona Ekonomi Eksklusif Indonesia, kendatipun memberikan kedaulatan dan wewenang kepada Pemerintah Republik Indonesia untuk mengatur eksplorasi dan eksploitasi sumberdaya alam hayati lingkungan laut tetapi senantiasa diiringi dengan kewajiban melakukan konservasi. Secara normatif, sepintas lalu perumusan norma dan atau kaidah dalam kedua undang-undang tersebut menunjukkan "pertentangan", karena disatu sisi, undang-undang memberikan wewenang untuk melakukan "eksplorasi" dan eksploitasi" terhadap kekayaan alam, namun di sisi lain, mendorong perlunya melakukan "konservasi". Dalam praktek, sulit untuk menggabungkan atau menyatukan antara "eksploitasi" dan "konservasi" dalam strategi

\footnotetext{
${ }^{4}$ Bagir Manan, Beberapa Catatan Atas Rancangan Undang-undang tentang Minyak dan Gas Bumi, Diskusi Panel RUU Migas, Fakultas Hukum Universitas Padjajaran Bandung, 1999, hlm. 1-2.
} 
pembangunan peisir lautan. Upaya mengedepankan salah satu dapat berakibat mengesampingkan yang lain, demikian sebaliknya.

Dalam kaitannya dengan upaya melakukan perlindungan (konservasi) lingkungan perairan Indonesia, telah diundangkan Undang Undang Nomor 6 Tahun 1996 tentang Perairan Indonesia, yang pada dasarnya memberikan wewenang kepada Pemerintah Republik Indonesia untuk melakukan pemanfaatan, pengelolaan, perlindungan dan pelestarian lingkungan perairan Indonesia. Untuk mengoptimalkan wewenang yang telah diberikan dalam undang-undang tersebut, undang-undang memberikan mandat untuk membentuk badan koordinasi yang ditetapkan dengan Keputusan Presiden (Pasal 23 ayat (3) Undang-Undang Nomor 6 Tahun 1996).

Di bidang penataan ruang, telah diundangkan Undang-Undang Nomor 26 Tahun 2007 (mencabut Undang-Undang Nomor 24 Tahun 1992) tentang Penataan Ruang. Dalam undang-undang ini tidak dijumpai secara eksplisit berkenaan dengan wewenang pengelolaan sumberdaya pesisir maupun lautan. Kendatipun dalam konsiderans disebutkan bahwa pengelolaan sumberdaya alam yang beranekaragam di daratan, di lautan dan di udara, perlu dilakukan secara terkoordinasi dan terpadu dengan sumberdaya manusia dan sumberdaya buatan dalam pola pembangunan yang berkelanjutan, namun materi yang diatur dalam batang tubuh undang-undang penataan ruang, masih terbatas atau masih didominasi pengaturan tata ruang daratan. Hal ini bisa dipahami karena dalam sejarah perjalanannya, yang menjadi leading sector-nya adalah Departemen Pekerjaan Umum, dan undang undang penataan ruang ini berdasarkan sejarahnya memang dihajatkan sebagai pengganti dari stadvormingsordonantie atau ordonansi pembentukan kota, Staatsblad Tahun 1948 Nomor 168.

Sejalan dengan undang-undang penataan ruang, dalam UndangUndang Nomor 23 Tahun 1997 tentang Pengelolaan Lingkungan Hidup, pun tidak secara eksplisit menyebutkan tentang wewenang pengelolaan sumberdaya pesisir dan lautan. Oleh karena itu, untuk menemukan dasar hukum wewenang dalam pengelolaan sumberdaya pesisir dan lautan dalam undang-undang pengelolaan lingkungan hidup, diperlukan metode penafsiran hukum. Berdasarkan ketentuan Bab IV tentang Wewenang Pengelolaan Hidup, Pasal 8 (ayat 1) menyebutkan bahwa "sumberdaya alam dikuasai oleh negara dan dipergunakan untuk sebesar-besarnya bagi kemakmuran rakyat serta pengaturannya ditentukan oleh Pemerintah". 
Sumberdaya alam sebagaimana dimaksudkan pada Pasal 8 ayat (1) dijabarkan lebih lanjut pada Pasal 9 ayat (3) yang meliputi sumberdaya alam non hayati, perlindungan sumberdaya buatan, konservasi sumberdaya alam hayati dan ekosistemnya, cagar budaya, keanekaragaman hayati dan perubahan iklim." Berdasarkan penafsiran ekstensif, konservasi sumberdaya alam hayati dan ekosistemnya itu juga harus meliputi sumberdaya alam hayati yang berada di daratan maupun di pesisir dan lautan.

Pengaturan sumberdaya alam oleh Pemerintah (pusat), sebagaimana tersebut pada Pasal 8 ayat (1), mengandung arti bahwa pengelolaan sumberdaya alam dan lingkungan bersifat sentralistik. Meskipun demikian, ada peluang untuk melimpahkan wewenang tertentu baik secara mandat kepada perangkat wilayah yang ada di daerah maupun pemberian secara delegasi kepada Pemerintah Daerah. Pasal 12 ayat (1), menyebutkan, bahwa :"untuk mewujudkan keterpaduan dan keserasian pelaksanaan kebijaksanaan nasional tentang pengelolaan lingkungan hidup, Pemerintah berdasarkan peraturan perundang-undangan dapat : a. melimpahkan wewenang tertentu pengelolaan lingkungan hidup kepada perangkat wilayah (mandat), b. mengikutsertakan peran Pemerintah Daerah untuk membantu Pemerintah Pusat dalam pelaksanaan pengelolaan lingkungan di daerah (mandat). Sedangkan Pasal 13 ayat (1) menegaskan, :"dalam rangka pelaksanaan pengelolaan lingkungan hidup, Pemerintah dapat menyerahkan sebagian urusan kepada Pemerintah Daerah menjadi urusan rumah tangganya" (delegasi).

Wewenang pengelolaan sumberdaya lautan juga bisa ditelusuri dalam Undang-Undang Nomor 5 Tahun 1990 tentang Konservasi Sumberdaya Alam Hayati dan Ekosistemnya jo Peraturan Pemerintah Nomor 68 Tahun 1998 tentang Kawasan Suaka Alam dan Kawasan Pelestarian Alam. Dalam Undang undang maupun Peraturan Pemerintah tersebut memang tidak disebut kata "lautan" tetapi disebut dengan "perairan". Pasal 1 angka 9 Undang-Undang Nomor 5 Tahun 1990, menyebutkan pengertian kawasan suaka alam sebagai kawasan dengan ciri khas tertentu, baik di darat maupun di perairan yang mempunyai tugas pokok sebagai kawasan pengawetan keanekaragaman tumbuhan dan satwa serta ekosistemnya yang juga berfungsi sebagai wilayah sistem penyangga kehidupan. Selanjutnya Pasal 1 angka 13 tentang kawasan pelestarian alam, disebutkan sebagai kawasan dengan ciri khas tertentu, baik di darat maupun di perairan yang mempunyai fungsi perlindungan sistem penyangga 
kehidupan, pengawetan keanekaragaman jenis tumbuhan dan satwa serta pemanfaatan secara lestari sumberdaya alam hayati dan ekosistemnya.

Dalam undang-undang nomor 5 tahun 1990 secara tegas menyebutkan bahwa pengelolaan kawasan suaka alam dan kawasan pelestarian alam merupakan kewenangan pemerintah pusat. Pasal 16 Undang-Undang Nomor 5 Tahun 1990 ayat (1) menyebutkan, bahwa :"pengelolaan kawasan suaka alam dilaksanakan oleh Pemerintah sebagai upaya pengawetan keanekaragaman tumbuhan dan satwa beserta ekosistemnya. Penjelasan Pasal ini menyebutkan, bahwa, :"pengelolaan kawasan suaka alam merupakan kewajiban Pemerintah sebagai konsekuensi penguasaan oleh negara atas sumberdaya alam sebagaimana dimaksud dalam Pasal 33 Undang-Undang dasar 1945". Walaupun demikian, dalam rangka pelaksanaan konservasi sumberdaya alam hayati dan ekosistemnya, Pemerintah pusat dapat menyerahkan sebagian urusan di bidang tersebut kepada daerah (delegasi), dan dapat juga menugaskan kepada daerah untuk melaksanakan urusan tersebut sebagai tugas pembantuan (mandat).

Berbeda dengan undang-undang sebelumnya, dalam Undang Undang Nomor 31 Tahun 2004 tentang Perikanan (sebagai pengganti UndangUndang nomor 9 Tahun 1985), mengatur secara tegas dan rinci mengenai wewenang pengelolaan sumberdaya perikanan. Namun demikian, jika diperhatikan dari aspek materi muatannya, menunjukkan perbedaan antara Undang-Undang nomor 31 tahun 2004 dengan Undang-Undang nomnor 5 Tahun 1990. Undang Undang nomor 5 Tahun 1990 mengedepankan aspek "conservation", sedangkan undang-undang perikanan tampaknya lebih mengedepankan "sustainable use", setidak-tidaknya pengertian itulah yang dijumpai dalam rumusan norma atau kaidah undang-undang tersebut. Dengan kata lain, Undang-Undang nomor 5 Tahun 1990, "konservasi" konservasi hayati dan ekosistemnya menjadi tujuan akhir dari pengelolaan, sedangkan undang undang perikanan, "konservasi" dihajatkan hanya sebagai "rambu-rambu" yang harus ditaati dalam rangka mencapai tujuan yang sesungguhnya, yaitu optimalisasi dan produktivitas pengelolaan sumberdaya ikan, artinya undang-undang perikanan ini sarat dengan muatan ekonomi. Pasal 1 angka 7 Undang-Undang nomor 31 Tahun 2004, menyebutkan, bahwa :" pengelolaan perikanan adalah semua upaya, termasuk proses yang terintegrasi dalam pengumpulan informasi, analisis, perencanaan, konsultasi, pembuatan keputusan, alokasi sumberdaya ikan dan implementasi serta penegakan hukum dan peraturan perundangundangan di bidang perikanan yang dilakukan oleh Pemerintah atau 
otoritas lain yang diarahkan untuk mencapai kelangsungan produktivitas sumberdaya hayati perairan dan tujuan yang telah disepakati".

Berkaitan dengan wewenang daerah dalam pengelolaan sumberdaya lautan, tercantum dalam Undang-Undang Nomor 32 Tahun 2004 tentang Pemerintahan Daerah (Lembaran Negara RI Tahun 2004, Nomor 125, Tambahan Lembaran Negara RI Nomor 4437). Ketentuan Pasal 18 ayat (1) menyebutkan : Daerah yang memiliki wilayah laut diberikan kewenangan untuk mengelola sumberdaya di wilayah laut.

Perumusan norma ini mengandung arti, bahwa sebelum diberikan kewenangan oleh Pemerintah Pusat, daerah tidak memilki wewenang untuk mengelola laut. Pemberian wewenang oleh Pemerintah Pusat kepada daerah berkaitan dengan urusan kelautan seperti tercantum dalam Pasal 18 Undang-Undang Nomor 32 Tahun 2004, pada dasarnya merupakan implementasi lebih lanjut dari ketentuan Pasal 33 UndangUndang Dasar 1945, yang menyebutkan :"bumi. Air, dan kekayaan alam yang terkandung didalamnya dikuasai oleh negara dan dipergunakan untuk sebesar-besar kemakmuran rakyat", oleh karena itu ketentuan Pasal 18 Undang-Undang Nomor 32 Tahun 2004 merupakan landasan yuridis adanya desentralisasi di bidang kelautan, yang diperoleh secara "delegasi" dari pemerintah pusat kepada pemerintah daerah.

Berbeda dengan rumusan Pasal 18 Undang-Undang Nomor 32 Tahun 2004, ketentuan Pasal 10 ayat (1) Undang-Undang Nomor 22 Tahun 1999, menyebutkan :"Daerah berwenang mengelola sumberdaya nasional yang tersedia di wilayahnya dan bertanggungjawab memelihara kelestarian lingkungan sesuai dengan peraturan perundang-undangan". Perumusan norma sedemikian mengandung arti adanya pembagian wewenang secara vertikal.

Menurut Philipus M. Hadjon, dengan mendasarkan pada ketentuan Undang-Undang Dasar 1945, terdapat 2 (dua) pola pembagian kekuasaan negara, yaitu pembagian kekuasaan secara horisontal dan secara vertikal. Pembagian kekuasaan negara secara horisontal adalah pembagian kekuasaan negara kepada organ utama negara yang dalam ketatanegaraan disebut Lembaga Negara, sedangkan pembagian kekuasaan negara secara vertikal adalah pembagian kekuasaan negara antar Pemerintah Pusat dan Pemerintah Daerah. ${ }^{5}$

${ }^{5}$ Pilipus M. Hadjon, Sistem Pembagian Kekuasaan Negara, Kuliah Umum di Universitas Wrma Dewa Denpasar Bali, Tanpa tahun, hlm. 1. 
Pembagian kekuasaan kekuasaan negara secara vertikal berdasarkan ketentuan Pasal 1 ayat (1) Undang-Undang Dasar 1945 bahwa Indonesia adalah negara kesatuan, apabila dikaitkan dengan ketentuan Pasal 18 Undang Undang Dasar 1945, maka sesungguhnya ide negara kesatuan tidaklah sentralistik. Oleh karena Undang Undang Dasar 1945 tidak merinci secara tegas tentang pelaksanaan asas desentralisasi dan sistem otonomi, dalam perjalanan sejarah ketatanegaraan Indonesia terdapat variasi pelaksanaan asas desentralisasi dan sistem otonomi daerah. Dengan demikian, dilihat dari hukum tatanegara mapun hukum administrasi negara, perumusan norma Pasal 10 ayat (1) dan (2) Undang-Undang Nomor 22 Tahun 1999 menunjukkan adanya desentralisasi di bidang lautan, dan daerah memperoleh kewenangan pengelolaan sumberdaya di wilayah laut secara "atributif".

\section{Kelembagaan Pengelolaan Sumberdaya Pesisir dan Lautan}

Di atas telah dikemukakan bahwa yang dimaksud dengan kelembagaan dibatasi pada pengertian institusi atau lembaga yang berkompeten baik secara langsung maupun tidak langsung berkaitan dengan pengelolaan sumberdaya pesisir dan lautan. Berdasarkan hasil inventarisasi, institusi yang berkaitan dengan pengelolaan sumberdaya pesisir dan lautan, antara lain : Departemen Energi dan Sumberdaya Mineral, Departemen Perhubungan, Kementerian Negara Pariwisata Seni dan Budaya, Departemen Kelautan dan Perikanan, Departemen Kehutanan, Departemen Luar Negeri, Departemen Pertahanan, TNI AL, Departemen Dalam Negeri, Departemen Keuangan, Kementerian negara Koperasi dan PPK, Bdan Pengkajian dan Penerapan Teknologi, Departemen Kehakiman dan HAM, Departemen Tenaga Kerja dan Administrasi, Kantor Kementerian Lingkungan Hidup, Menko EKUINm Bappaenas, Kepolisian (Polairud), Lembaga Pertahanan dan Keamanan Nasional (LEMHANAS), masing-masing memiliki kewenangan dan tanggung jawab serta cakupan teritorial laut yang berbeda satu sama lain.

Keberadaan lembaga tersebut di atas menunjukkan bahwa tanggungjawab atau kewenangan pembangunan kelautan melibatkan berbagai institusi, oleh karena itu tidak mungkin pembangunan kelautan dalam pengertian yang luas dapat dilakukan oleh sebuah institusi negara yang memiliki kewenangan terbatas seperti Departemen Kalautan dan Perikanan. Apabila bidang kelautan dihajatkan menjadi sebuah sektor unggulan dalam perekonomian nasional agar dapat mensejahterakan 
masyarakat, maka diperlukan suatu kebijakan pembangunan yang bersifat terintegrasi antar institusi pemerintah dan sektor pembangunan.

Untuk mengarah pada hal itu, menurut Tridoyo, diperlukan sebuah kebijakan pembangunan kelautan (ocean development policy) sebagai bagian dari ocean policy yang nantinya menjadi "payung" dalam mengambil sebuah kebijakan yang bersifat publik. Penciptaan payung ini dibangun oleh sebuah pendekatan kelembagaan (institutional arrangement) yang lingkupnya mencakup dua domein dalam suatu sistem pemerintahan, yakni legislatif dan eksekutif. Pada level legislatif, dengan fungsi yang dimilikinya berdasarkan undang-undang seperti fungsi legislasi, fungsi budgeting dan fungsi controlling, diharapkan lembaga ini mampu menciptakan instrumen kelembagaan berupa (peraturan perundang-undangan) pada level pusat maupun daerah untuk mendukung kebijakan pembangunan kelautan. Sedangkan pada level eksekutif, diharapkan institusi kelembagaan yang terkait dengan lautan dapat melaksanakan kerjasama membangun sinergi dalam rangka pencapaian tujuan pembangunan sektor kelautan. ${ }^{6}$

Dalam membangun sinergi hubungan antar institusi kelembagaan yang terkait dengan lautan, acapkali terjadi permasalahan di tingkat sektor yang disebabkan karena perbedaan penafsiran didalam memahami peraturan perundang-undangan khususnya yang menyangkut tugas pokok dan fungsi atau wewenang berdasarkan peraturan perundangan yang menjadi dasar dari masing-masing sektor.

Dalam perspektif jangka panjang, seperti telah diutarakan sebelumnya, ke-ego-an sektoral dapat berakibat kontra produktif dalam pembangunan pesisir dan lautan secara berkelanjutan. Oleh karena itu, diperlukan kesamaan pandangan untuk melihat tujuan yang lebih besar yakni pembangunan nasional di bidang lautan sebagaimana tertuang dalam Program Pembangunan Nasional (Propenas). Berkenaan dengan hal tersebut, persoalan keterpaduan menjadi sangat penting sebagai solusi untuk meminimalisir agar tidak terjadi arogansi sektoral yang dapat merugikan kepentingan nasional di bidang lautan.

${ }^{6}$ Tridoyo Kusumastanto, Rekonstruksi Kebijakan Pembangunan Kelautan, makalah disampaikan pada "Indonesia Ocean Outlook 2004" Laut masa depan Bangsa", Pusat kajian Sumberdaya Pesisir dan Lautan, Institut Pertanian Bogor, 2004, hlm. 13 


\section{Keterpaduan Pengelolaan Sumberdaya Pesisir dan Lautan}

"Keterpaduan", merupakan kata kunci yang acapkali diperlukan sebagai upaya mencari dan menemukan solusi atas berbagai persoalan yang muncul akibat terjadinya tumpang tindih kegiatan, terjadinya perselisihan wewenang antara berbagai kelembagaan serta persoalan kompleks lainnya. Kendatipun kata "keterpaduan" disebutkan secara eksplisit dalam berbagai peraturan perundang-undangan, namun dalam praktek, sulit untuk mewujudkan menjadi kenyataan.

Di bidang kelautan, persoalan keterpaduan dan atau koordinasi menjadi sesuatu yang mendesak untuk segera dilakukan. Ada beberapa aspek pengelolaan lautan yang menjadi isu besar yang mencakup aspek ekonomi, ekologi, oceanografi, jasa, pariwisata, sosial budaya, yang kesemuanya membutuhkan keterpaduan sebagai solusi untuk mengeleminir terjadinya ego-sektoral di kalangan beberapa instansi yang menangani urusan lautan. Di sisi lain, kondisi faktual menunjukkan bahwa kebijakan pembangunan kelautan masih berjalan sendiri-sendiri. Beberapa institusi negara yang berkepentingan dengan pesisir dan laut, membuat kebijakan yang lebih bersifat sektoral. Harus diakui, bahwa saat ini belum ada mekanisme atau aransemen kelembagaan yang mampu mensinergikan dan memadukan kebijakan pembangunan pesisir dan lautan. Dampaknya penanganan kasus dalam pembangunan pesisir dan lautan acapkali menimbulkan konflik kepentingan. Penyelesaian kasus pasir laut di Riau merupakan salah satu contoh konflik antar institusi negara, yakni Departemen Energi dan Sumberdaya Mineral, Departemen Perindustrian dan Perdagangan dan Departemen Kelautan dan Perikanan.

Tabel 1

\begin{tabular}{|l|l|l|l|}
\hline No & Isu-isu Pokok & \multicolumn{1}{|c|}{ Problem } & Keterkaitan Lembaga \\
\hline 1. & Pasir Laut & - Kerusakan & - Departemen Energi \\
& Pertambangan & lingkungan & dan Mineral \\
& Laut & - Eksploitasi ilegal & - Depertemen Kelautan \\
& & - Berkurangnya mata & dan Perikanan \\
& & pencaharian nelayan & - Deperindag \\
& & - Konflik kepentingan & - TNI - AL \\
& & pusat dan daerah & - Meneg Lingkungan \\
& & - Adanya indikasi KKN & Hidup \\
\hline
\end{tabular}




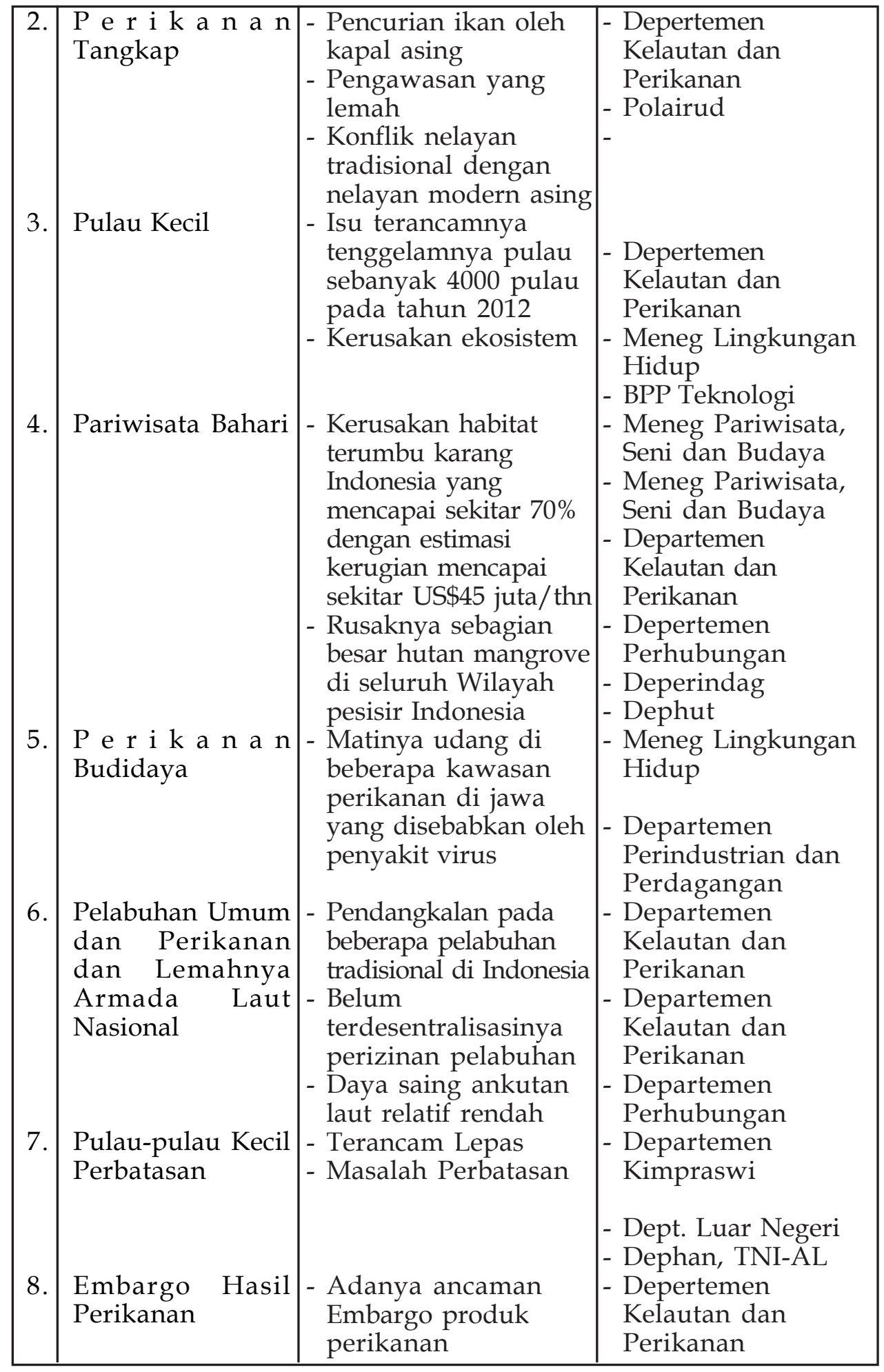




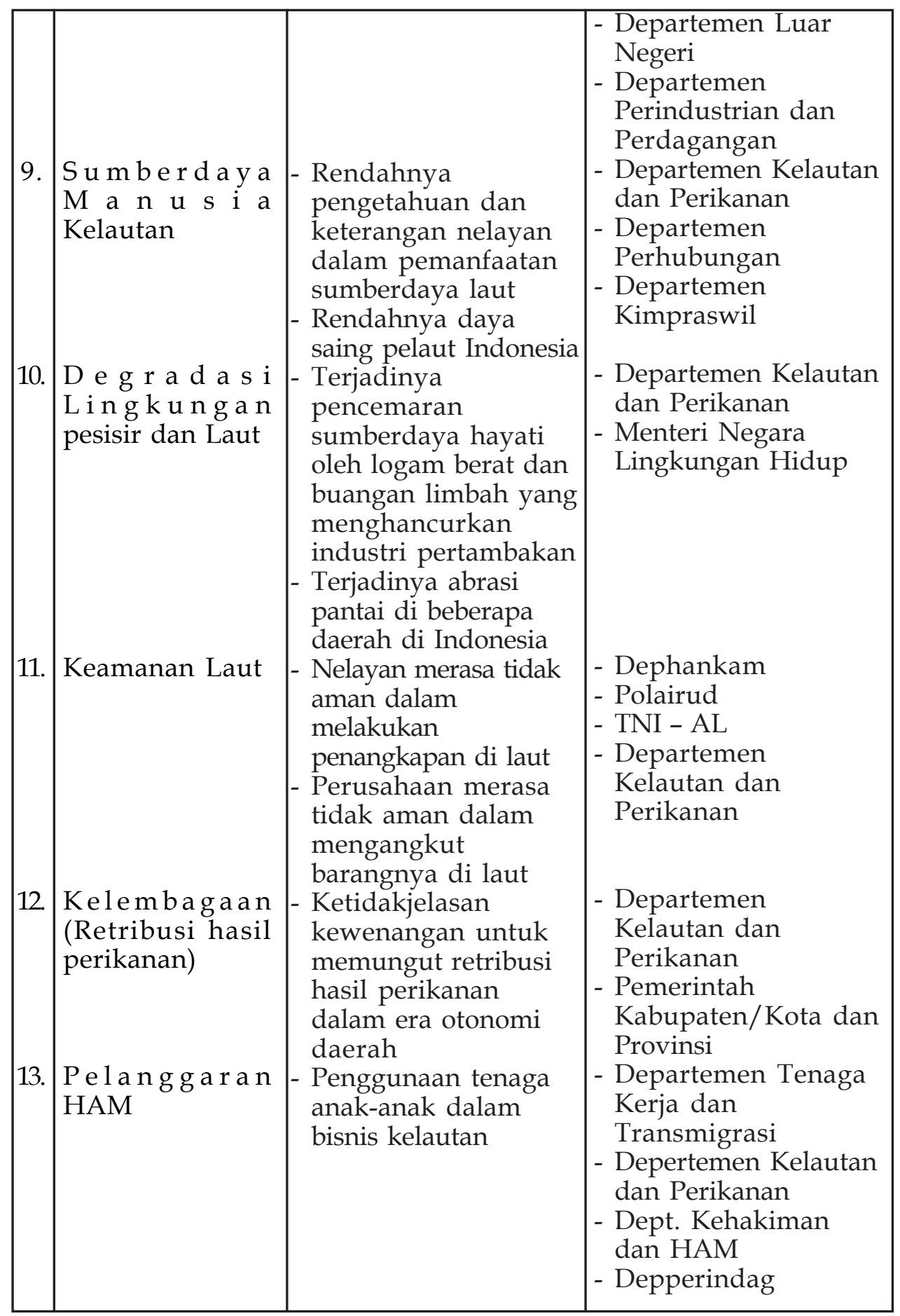




\begin{tabular}{|l|l|l|l|}
\hline 14. UKM Kelautan & $\begin{array}{l}\text { - Peluang Terjadinya } \\
\text { kebocoran } \\
\text { - Mekanisme } \\
\text { pengelolaan dan } \\
\text { pengalokasikan }\end{array}$ & $\begin{array}{l}\text { - Depertemen Kelautan } \\
\text { dan Perikanan } \\
\text { - Bank Indonesia, Bank } \\
\text { pelaksana } \\
\text { - Meneg koperasi dan } \\
\text { PPK }\end{array}$ \\
\hline
\end{tabular}

Berdasarkan hasil kajian yang dilakukan Tridoyo dari berbagai sumber, diperoleh keterangan mengenai isu pokok dan masalah di bidang kelautan serta keterkaitan kelembagaan, seperti dalam tabel di bawah.?

Untuk melakukan keterpaduan atau koordinasi agar menghasilkan pengelolaan pesisir yang efektif, Morten Edvardsen mengemukakan ada 4 dimensi, yaitu : 8

a. Horizontal integration of policies, management arrangements and development plans (amongst different sectors, services, and agencies);

b. Vertical integration of policies, management arrangements and development plans (from national through to local levels of government);

c. Territorial integration taking into account the interrelationships and interdependencies between terrestrial, estuarine, littoral, and offshore components of the zone;

d. The consistent integration of policies, plan and management strategies through time.

Secara lebih spesifik, Tommy Poerwaka, berpendapat bahwa untuk mewujudkan pengelolaan terpadu, maka lembaga-lembaga yang terkait dalam pengelolaan sumberdaya wilayah pesisir dan lautan harus mengetahui kegiatan apa saja yang dapat dan tidak dapat dipadukan dan bagaimana cara memadukannya. Secara sederhana Tommy, berpendapat bahwa dua kegiatan atau lebih dapat dipadukan apabila memenuhi asas kompatibilitas yang terdiri dari tiga macam, yaitu complete compatibility, partial compatibility dan incompatibility. Complete compatibility terjadi apabila dua atau kegiatan atau lebih dapat berlangsung bersamaan dalam ruang dan waktu yang sama; partial compatibility, terjadi apabila dua kegiatan atau lebih dapat dilakukan secara berurutan dalam

\footnotetext{
${ }^{7}$ Tridoyo Kusumastanto, Ocean Policy dalam Membangun Negeri Bahari di Era Otonomi Daerah, Gramedia Pustaka utama, Jakarta, 2003, hlm. 16-17

${ }^{8}$ Morten Edvardsen, Coastal Zona Planing and Management in the North Sea RegionOrganizational Aspects, dalam Jurnal litoral, 2002, The Changing Coast EUROCOASTPorto Portugal, hlm. 111
} 
ruang yang sama, namun dalam waktu yang berbeda, dan incompatibility terjadi apabila dua kegiatan tidak dapat dilakukan secara bersamaan atau berurutan dalam ruang yang sama. ${ }^{9}$

Dalam praktek, kegiatan yang mudah dipadukan adalah kegiatan yang bersifat jasa (services) seperti pembuatan rencana dan program bersama, kegiatan yang agak sulit dipadukan adalah kegiatan untuk membuat atau merumuskan aturan main bersama (norm creation), dan kegiatan yang sulit dipadukan adalah kegiatan yang berkaitan dengan implementasi dari aturan main yang telah disepakati bersama berikut pengawasannya (implementation and rules observance). Apabila diterapkan dalam pengelolaan sumberdaya pesisir dan lautan, dapat dikatakan bahwa aspek perencanaan (planning) sumberdaya lautan termasuk kategori mudah, organizing atau merumuskannya agak sulit dan pelaksanaan dan pengawasan (actuating and controlling) sumberdaya lautan itu termasuk kategori sulit.

Kendatipun demikian, ukuran mudah maupun sulit, pada dasarnya juga relatif dan bersifat kasuistis. Relatif, artinya sesuatu yang tampaknya mudah tetapi kenyataannya bisa saja justeru menjadi sulit, demikian pula sebaliknya, Kasuistis, artinya kesemuanya tergantung dari kasus posisinya masing-masing. Pada setiap tahapan dalam proses manajemen, senantiasa dijumpai kasus yang perlu diselesaikan. Pada tahap perencanaan misalnya, meningkatnya kegiatan pembangunan yang memerlukan lahan di kawasan pesisir, baik tempat untuk memperoleh sumberdaya alam mineral maupun sebagai lokasi kegiatan ekonomi lainnya, telah meningkatkan terjadinya kasus konflik pemanfaatan ruang pesisir serta pengaruh buruk dari satu kegiatan terhadap kegiatan lainnya, oleh karena itu diperlukan perencanaan tata ruang pesisir yang baik, artinya merupakan kegiatan penentuan rencana lokasi berbagai kegiatan dalam ruang bagi pemanfaatan ruang dan sumber daya yang terdapat di dalamnya secara optimal.

Dari penjelasan di atas, dapat ditegaskan bahwa melalui pendekatan kelembagaan (institutional approach), dengan cara melakukan penataan wewenang dan kelembagaan, dapat menciptakan efisiensi dan efektivitas dalam pengelolaan sumberdaya pesisir dan lautan. Penataan wewenang dan kelembagaan juga perlu diiringi dengan penyempurnaan prosedur

${ }^{9}$ Tommy Poerwaka, Sistem Hukum dan Kelembagaan dalam Pengelolaan Sumberdaya Wilayah Pesisir dan Lautan, (makalah), Jakarta, 2002 
atau mekanisme. Hal ini penting, mengingat di kawasan pesisir acapkali terjadi akumulasi berbagai kegiatan masyarakat baik secara pribadi maupun dalam bentuk badan hukum memanfaatkan kawasan pesisir, tak jarang juga dalam memanfaatkan kawasan pesisir membutuhkan izin dari Pejabat yang berwenang melalui instusi yang bertanggungjawab. Dalam hal yang sedemikian, hukum dalam arti wewenang dan kelembagaan pengelolaan sumberdaya pesisir, harus dibuat sedemikian rupa agar dapat mendayagunakan potensi ekonomi yang ada di kawasan

pesisir. Demikian pula, prosedur atau mekanisme dibuat sesedehana mungkin untuk memudahkan segenap lapisan masyarakat dapat berpartisipasi dalam memanfaatkan potensi kawasan pesisir. Kesemuanya dilakukan dengan tetap menjaga agar konservasi dan perlindungan pesisir juga dapat dilakukan seoptimal mungkin.

\section{Penutup}

Berdasarkan apa yang telah diuraikan di atas, dapat disimpulkan bahwa, wewenang pengelolaan sumberdaya pesisir dan lautan, tersebar dalam berbagai peraturan perundang-undangan (sektoral), seperti pariwisata, lingkungan, tata ruang, pertanahan, pertambangan, kehutanan dan sebagainya. Akibatnya lembaga atau instansi yang menangani persoalan pesisir dan laut pun cukup beragam. Banyaknya lembaga yang menangani pesisir dan laut, potensial dapat mengakibatkan terjadinya perselisihan wewenang antar instansi, dari sudut institusi, kegiatan yang saling terkait secara lintas sektoral, terjadinya tumpang tindih kegiatan, dan makin potensialnya konflik wewenang dan kepentingan tersebut, mengharuskan sistem institusi dengan keterpaduan sebagai ciri utamanya. Dalam kaitan ini, maka pengelolaan sumberdaya pesisir membutuhkan asas-asas hukum antar wewenang agar jelas siapa, melakukan apa dan kaidah hukum apa yang harus berlaku apabila terjadi konflik antar instansi. Pendekatan kelembagaan (institutional approach) melalui penataan wewenang, lembaga (institusi) dan prosedur dalam pengelolaan sumberdaya pesisir, merupakan salah satu langkah strategis dalam mendorong peningkatan efisisensi dan efektivitas dalam pengelolaan sumberdaya pesisir secara berkelanjutan. 


\section{Daftar Pustaka}

Bagir Manan, Beberapa Catatan Atas Rancangan Undang-undang tentang Minyak dan Gas Bumi, Diskusi Panel RUU Migas, Fakultas Hukum Universitas Pajajaran, Bandung, 1999.

Mochtar Kusumaatmadja, Fungsi Hukum dalam Pembangunan Nasional, Lembaga Kriminolgi Universitas Pajajaran Bandung, 1976

Morten Edvardsen, Coastal Zone Planning and Management in the North Sea Region - Organizational Aspects, dalam Jurnal Litoral, 2002, The Changing Coast EUROCOAST - Porto Portugal.

Philipus M. Hadjon, Tentang Wewenang, Yuridika, Nomor 5\&6 XII September-Desember 1999.

- Sistem Pembagian Kekuasaan Negara, Kuliah umum di Universitas Warma Dewa Denpasar Bali, tanpa tahun.

Rokhmin Dahuri (et.al), Pengelolaan Sumberdaya Wilayah Pesisir dan Lautan Secara Terpadu, Pradnya Paramitha, Jakarta, 1996

Soewoto, Kekuasaan dan Tanggungjawab Presiden Republik Indonesia (disertasi) Fakultas Pasca sarjana Universitas Airlangga, Surabaya, 1990.

Siti Sundari Rangkuti, Hukum Lingkungan dan Kebijaksanaan Lingkungan Indonesia (edisi ketiga), Airlangga University, Surabaya, 2005.

Tommy Poerwaka, Sistem Hukum dan Kelembagaan dalam Pengelolaan Sumberdaya Wilayah Pesisir dan Lautan, (makalah), Jakarta, 2002.

- Hukum dan Perundang-undangan Bidang Kelautan dan perikanan, makalah disampaikan pada Pelatihan Dosen PTN/PTS se Indonesia tentang Perencanaan dan Pengelolaan Sumberdaya Pesisir dan Laut sebagai Upaya Pemberdayaan Masyarakat Pesisir Secara Berkelanjutan, Kerjasama Bagpro PKSDM DIKTI Depdiknas dan Universitas Mataram, 2004.

Tridoyo Kusumastanto, Rekonstruksi Kebijakan Pembangunan Kelautan, makalah disampaikan pada "Indonesia Ocean Outlook 2004" Laut Masa Depan Bangsa", Pusat Kajian Sumberdaya Pesisir dan Lautan, Institut Pertanian Bogor, 2004,

Ocean Policy dalam Membangun Negeri Bahari di Era Otonomi Daerah, Gramedia Pustaka Utama, Jakarta, 2003,

- Reposisi "Ocean Policy" dalam pembangunan Ekonomi Indonesia di Era Otonomi9 Daerah, (Pidato Orasi Ilmiah Sebagai Guru Besar Ilmu Kelautan dan Perikanan pada Institut Pertanian Bogor, 2002 